\title{
The Effect of Harvesting and Replanting on Arthropod Ground Predators in Florida Sugarcane ${ }^{1}$
}

\section{Ronald Cherry and Robert Gilbert ${ }^{2}$}

Sugarcane (Saccharum spp.) is a major field crop in Florida and is primarily grown in the Everglades Agricultural Area of southern Florida. Several studies have been published about various biological control agents in Florida sugarcane (see Hall, 1988; Hall and Bennett, 1994). However, these studies do not include information on the population dynamics of arthropod ground predators in Florida sugarcane. Arthropod predators include various species of ants, spiders, and beetles which may serve as indicator species for overall health of the insect ecosystem within a given field. Florida sugarcane is a long-term crop and few tillage practices are required over the entire course of a 3 to 5 year planting (Hall and Bennett 1994). Hence, what the effect of yearly harvesting and eventual replanting of sugarcane is on arthropod ground predators is an interesting question. The population dynamics of arthropod ground predators such as ants, spiders, and beetles have important implications for Integrated Pest Management strategies in sugarcane, and may be indicative of the stability of the Florida sugarcane ecosystem. This fact sheet summarizes the effects of sugarcane harvesting and planting on these predators during a one-year study.

\section{Arthropod Ground Predators Present in Sugarcane Fields}

A total of 4,255 arthropod ground predators were caught in 20 pitfall traps in 4 Florida sugarcane fields during the one year study, which examined both ratooned and successively planted (sugarcane after sugarcane) fields (Table 1). Of these, the vast majority caught (67.6\%) were ants. Among ants, the imported fire ant, Solenopsis invicta Buren was clearly the dominant ant species being $79.2 \%$ of all ants found in traps. These data are consistent with the report of Cherry and Nuessly (1992) that showed that S. invicta had become the dominant ant species in Florida sugarcane since first being found there in 1970. In fact, more S. invicta $(2,279)$ were caught in pitfall traps in this study than all other predators combined. There is a wealth of literature on S. invicta as a predator in sugarcane and other ecosystems and this is reviewed by Reagan (1986).

1. This document is ENY-696, one of a series of the Entomology and Nematology Department, Florida Cooperative Extension Service, Institute of Food and Agricultural Sciences, University of Florida. First published: January 2004. Please visit the EDIS Web site at http://edis.ifas.ufl.edu/. The authors thank Dr. G.B. Edwards of the Division of Plant Industry, Gainesville, FL for help in identifying spiders.

2. Ronald H. Cherry, professor, Everglades REC-Belle Glade, Entomology and Nematology Department, and Robert Gilbert, assistant professor, Everglades REC-Belle Glade, Department of Agronomy, Cooperative Extension Service, Institute of Food and Agricultural Sciences, University of Florida, Gainesville, 32611.

The Institute of Food and Agricultural Sciences is an equal opportunity/affirmative action employer authorized to provide research, educational information and other services only to individuals and institutions that function without regard to race, color, sex, age, handicap, or national origin. For information on obtaining other extension publications, contact your county Cooperative Extension Service office. Florida Cooperative Extension Service/Institute of Food and Agricultural Sciences/University of Florida/Christine Taylor Waddill, Dean. 
Table 1. Relative abundance of arthropod ground predators caught in pitfall traps in Florida sugarcane fields.

\begin{tabular}{||l|r|r||}
\hline \hline \multicolumn{1}{|c|}{ Predator } & Number & $\begin{array}{r}\text { Percent of } \\
\text { total catch }\end{array}$ \\
\hline Ants & 2877 & 67.6 \\
\hline $\begin{array}{l}- \text { Brachymyrmex } \\
\text { obscurior Forel }\end{array}$ & 50 & 1.2 \\
\hline $\begin{array}{l}- \text { Monomorium } \\
\text { pharaonis (Linn.) }\end{array}$ & 52 & 1.2 \\
\hline $\begin{array}{l}\text {-Odontomachus } \\
\text { ruginodis Wheeler }\end{array}$ & 96 & 2.3 \\
\hline $\begin{array}{l}\text {-Pheidole moerens } \\
\text { Wheeler }\end{array}$ & 126 & 3.0 \\
\hline $\begin{array}{l}\text {-Solenopsis invicta } \\
\text { Buren }\end{array}$ & 2279 & 53.4 \\
\hline $\begin{array}{l}\text {-Strumigenys } \\
\text { louisianae Roger }\end{array}$ & 46 & 1.1 \\
\hline $\begin{array}{l}\text {-Tetramorium } \\
\text { simillimum Smith }\end{array}$ & 65 & 1.5 \\
\hline $\begin{array}{l}\text {-Wasmannia } \\
\text { auropunctata (Roger) }\end{array}$ & 60 & 1.4 \\
\hline -Unknown & 109 & 2.6 \\
\hline Earwigs & 252 & 5.9 \\
\hline Ground Beetles & 76 & 1.8 \\
\hline Rove Beetles & 89 & 2.1 \\
\hline Spiders & 913 & 21.5 \\
\hline -Corinnidae & 116 & 2.7 \\
\hline -Gnaphosidae & 49 & 1.2 \\
\hline -Linyphiidae & 69 & 1.6 \\
\hline -Lycosidae & 633 & 14.9 \\
\hline -Unknown & 46 & 1.1 \\
\hline Centipedes & 4255 & 100.0 \\
\hline \hline
\end{tabular}

\section{Effect of Harvest and Replanting on Arthropod Ground Predators in Sugarcane}

Hall and Bennett (1994) have noted that insect pests of sugarcane are good candidates for classical biological control because some pest damage may be generally tolerated, sugarcane is a long term crop, and few tillage practices are required over the entire course of the three to five year planting. They also note that pre-harvest burning is the most disruptive practice that may interfere with biological control. However, the effects of burning on arthropod populations are complex and not always predictable. For example, ants were the most frequently caught predators in this study and MacKay et al. (1991) noted that fire may reduce species richness of ants, increase ant activity, or have no effect on ant populations. Pitfall studies show that there were large differences in catches of ants, spiders, and total predator numbers among different months in ratooned fields (Figure 1). However, there were no significant differences in catches of these groups in the month immediately preceding harvest and following harvest in ratooned fields. Also, catches of these groups during the three month post-harvest period were not significantly different than the three month pre-harvest period. These data show that the sugarcane harvesting, including the burning of the fields, did not reduce overall activity of ants, spiders, or total ground predator number caught in pitfall traps in ratooned fields.

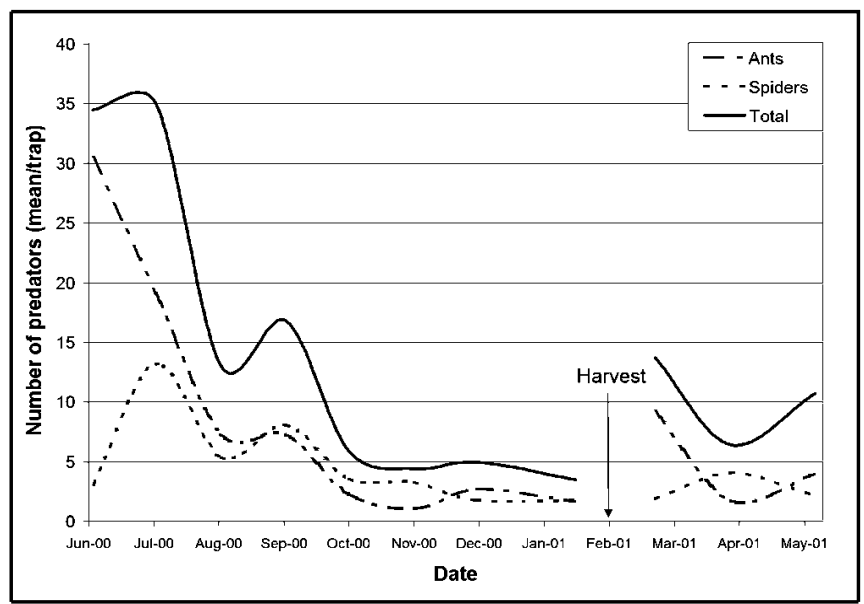

Figure 1. Arthropod predators - ratooned fields.

Predator catches in pitfall traps in successively planted fields of Florida sugarcane are shown in Figure 2. Pitfall trap catches of ants, spiders, and total predators all showed large decreases in the month following replanting versus the month immediately before replanting. Also, total ground predator catches remained low for the first four months after replanting compared to pre-planting catches and then increased dramatically at five to six months after planting. These data make sense since replanting is more disruptive to the soil habitat than harvesting because replanting involves not only burning of the field and mechanical harvesting, but also disking, and the use of a soil insecticide. 


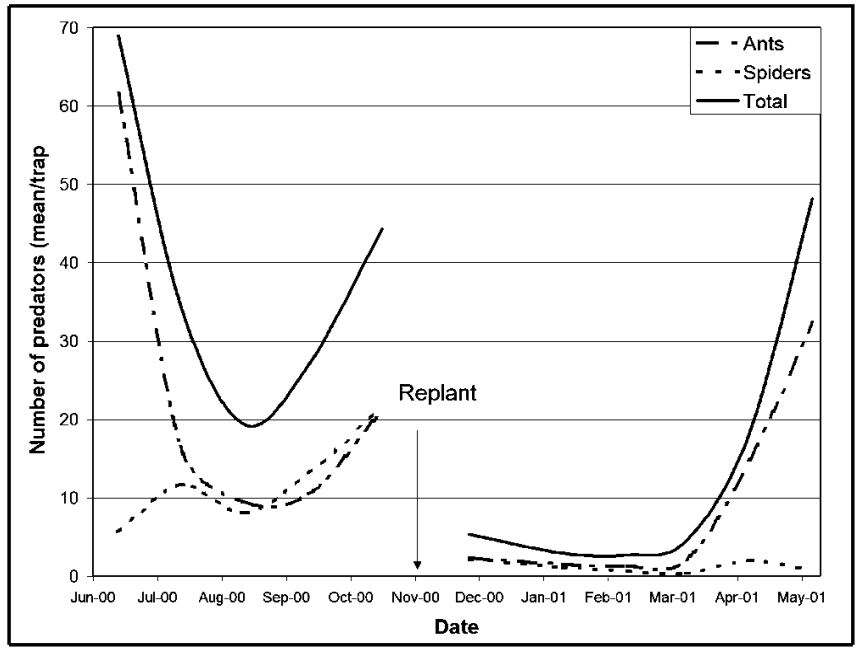

Figure 2. Arthropod predators - replanted fields.

\section{Conclusions}

To summarize, sugarcane harvesting had no significant effect on total numbers of arthropod ground predators caught in pitfall traps. In contrast, replanting significantly reduced total numbers of ground predators in pitfall traps, but these numbers resurged after 5 to 6 months to preharvest levels. These data show that through most of its 3 to 5 year crop cycle, Florida sugarcane is a stable ecosystem at ground level for most arthropod ground predators. The stability of the sugarcane agroecosystem for ground predators is in contrast to many other agricultural field crops, and may be helpful in the development of Integrated Pest Management strategies in sugarcane that would utilize arthropod ground predators to control insect pests. For more details concerning this study, see Cherry (2003).

\section{References Cited}

Cherry, R. 2003. The effect of harvesting and replanting on arthropod ground predators in Florida sugarcane. Florida Entomol. 86:49-52.

Cherry, R., and G. Nuessly. 1992. Distribution and abundance of imported fire ants (Hymenoptera: Formicidae) in Florida sugarcane fields. Environ. Entomol. 21: 767-770.

Hall, D. 1988. Insects and mites associated with sugarcane in Florida. Florida Entomol. 71: 138-150.

Hall, D., and F. Bennett. 1994. Biological control and IPM of sugarcane pests in Florida, pp. 297-325. In D. Rosen, F. Bennett, and J. Capinera (eds.). Pest management in the subtropics: biological control - A Florida perspective.. Intercept. Paris.

MacKay, W., A. Rebeles, H. Arrendo, A. Rodriguez, D. Gonzales, and S. Vinson. 1991. Impact of the slashing and burning of a tropical rain forest on the native ant fauna (Hymenoptera: Formicidae).

Sociobiology. 18: 257-268.

Reagan, T. 1986. Beneficial aspects of the imported fire ant: a field ecology approach, $\mathrm{pp}$. 58-71. In C. Lofgren and R. Vander Meer (eds.). Fire ants and Leaf-cutting ants - biology and management. Westview press. London. 